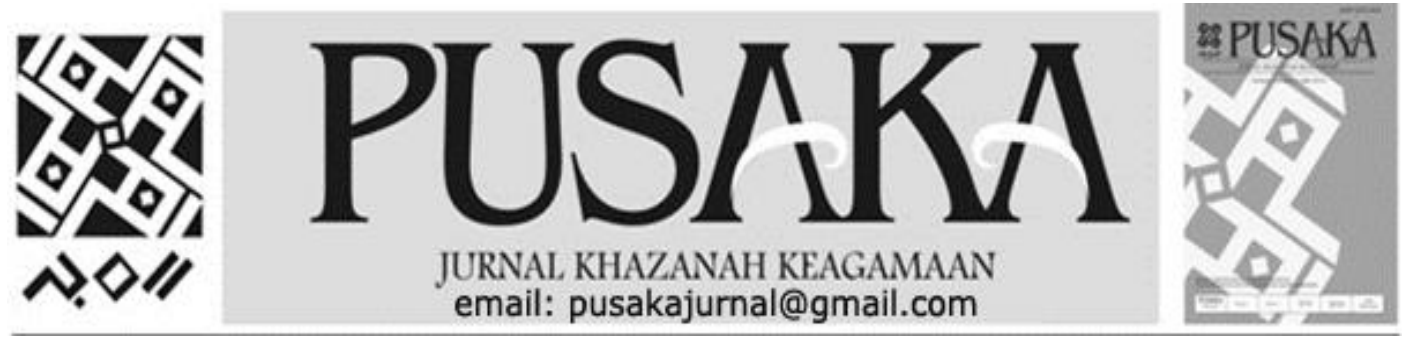

\title{
Moderasi Beragama dalam Masossor Manurung di Bumi Manakarra Provinsi Sulawesi Barat
}

\section{Religious Moderation in Masossor Manurung in Bumi Manakarra, West Sulawesi Province}

Wardiah Hamid

Balai Penelitian dan Pengembangan Agama

Jl. AP. Pettarani No. 72 Makassar

Email: hamidwardiah722@gmail.com

\begin{tabular}{|c|c|}
\hline $\begin{array}{c}\text { Info } \\
\text { Artikel }\end{array}$ & Abstract \\
\hline $\begin{array}{c}\text { Diterima } \\
13 \\
\text { Maret } \\
2020 \\
\\
\text { Revisi I } \\
10 \\
\text { April } \\
2021\end{array}$ & $\begin{array}{l}\text { Penelitian ini bertujuan untuk menggambarkan Moderasi Beragama dalam } \\
\text { Masossor Manurung di Bumi Manakarra Provinsi Sulawesi Barat. Dimana } \\
\text { berbagai kearifan lokal tumbuh dan mengandung nilai moderasi beragama } \\
\text { diantaranya falsafah-falsafah hidup orang Mandar. Dan yang secara spesifik } \\
\text { melihat secara mendalam Masossor Manurung menjadi ritual dan event penting } \\
\text { konsolidasi keberagaman bagi masyarakat di tanah Manakarra. Metode } \\
\text { pengumpulan data yang pergunakan yaitu wawancara mendalam dengan } \\
\text { informan, studi dokumen dan observasi lapangan. Temuan lapangan menunjukan } \\
\text { bahwa moderasi beragama dalam Masossor Manurung di Bumi Manakarra } \\
\text { Provinsi Sulawesi Barat yang berkembang berupa falsafah-falsafah dan secara } \\
\text { spesifik ritual masossor manurung memberi pengaruh efektif membangun potensi } \\
\text { moderasi beragama tanpa memandang perbedaan agama dan suku. Kesulitan } \\
\text { tentang perbedaan yang melingkupi kemajemukan kadang menjadi bias perbedaan } \\
\text { yang saling mencurigai dan menjadi kekacauan suatu wilayah. Tetapi leluhur } \\
\text { orang-orang Manakarra sangat jeli melihat kondisi di masa depan. Mereka } \\
\text { menanamkan berbagai wejangan lewat falsafah hidup dan ritual untuk saling } \\
\text { menghargai di dalam perbedaan agama suku dan strata sosial. }\end{array}$ \\
\hline $\begin{array}{c}\text { Revisi II } \\
04 \\
\text { Mei }\end{array}$ & Kata Kunci: kearifan lokal, masossor manurung, moderasi \\
\hline $\begin{array}{c}\text { Disetujui } \\
30 \\
\text { Mei } \\
2021\end{array}$ & $\begin{array}{l}\text { This study aims to describe the Religious Moderation in local wisdom in Bumi } \\
\text { Manakarra, West Sulawesi Province. Where various local wisdoms grow and } \\
\text { contain religious moderation values including the philosophies of life of the } \\
\text { Mandar people. And who specifically saw in depth Masossor Manurung become } \\
\text { an important ritual and event for the consolidation of diversity for the people of } \\
\text { Manakarra. Data collection methods used are in-depth interviews with } \\
\text { informants, document studies and field observations. Field findings show that } \\
\text { religious moderation in local wisdom in Mamuju, West Sulawesi Province, has } \\
\text { developed in the form of philosophies and specifically the Masossor Manurung } \\
\text { ritual has an effective influence in building the potential for religious moderation } \\
\text { regardless of religious and ethnic differences. Difficulties about differences } \\
\text { surrounding diversity can sometimes be biased differences that mutually suspect } \\
\text { and become chaos in a region. But the ancestors of the people of Manakarra were } \\
\text { very keen to see the conditions in the future. They instill various teachings through }\end{array}$ \\
\hline
\end{tabular}


the philosophy of life and rituals to respect each other in the differences in ethnic religion and social strata.

Keywoards: local wisdom, masossor manurung, moderation

\section{PENDAHULUAN}

Penduduk Indonesia begitu beragam dari segi suku, agama, dan etnis. Keragaman ini adalah hal yang alamiah dan merupakan Sunnatullah. Perbedaan yang beragam ini seharusnya dimanajmen sedemikian rupa dalam melahirkan keindahan yang saling menghormati perbedaaan tersebut. Keragaman itu adalah identitas yang dimiliki setiap suku atau pun individu. Rajutan keragaman diantara sesama anak bangsa begitu elok jika dikelola secara baik. Pengelolaannya juga bisa ditempuh dalam berbagai cara. Salah satu cara yang ingin dikaji adalah moderasi beragama dalam kearifan lokal. Moderasi beragama adalah keseimbangan, dan keadilan dalam memahami perbedaan yang berusaha memahami kemajemukan dalam bingkai perdamaian.

Fenomena prilaku menyimpang sangat tidak dibenarkan dalam agama mana pun. Kerusakan yang diakibatkan chaos adalah ujung dari tidak adanya penghargaaan dan saling menghormati diantara sesama umat manusia. Padahal Tuhan telah memberikan contoh yang begitu jelas perputaran siang dan malam adalah untuk menjaga keseimbangan alam. Siang dan malam tidak pernah saling mendahului, mereka saling memberikan ruang dan waktu untuk memberikan pelajaran kepada manusia bahwa perbedaan merupakan hukumm alam yang pasti.
Sisi pertengahan (keadilan) serta keseimbanganlah yang dapat memelihara hubungan antara "kemajemukan" perbedaan, pluralitas dan faktor kesamaan, pengikat, dan kesatuan. Sementara itu disintegrasi dan kacau-balau ditimbulkan oleh sikap ekstrem memusuhi menyempal' yang tidak mengakui dan tidak memliki faktor pemersatu (Imarah, 1999, p. 10). Toleransi membuat keragaman menjadi mungkin, keragaman membuat toleransi menjadi penting (Walzer, 1997).

Zaman digital sekarang ini menembus ruang dan waktu tanpa sadar ataupun sadar sebahagian generasi kita terpapar oleh pemikiran menghujat merasa benar sendiri tanpa mencoba menakar dan menelusuri kebenaran lain selain yang mereka ketahui. Teror bom atau teror pemikiran dan rasa menang sendiri adalah sikap yang mengedepankan egoisme yang berujung kepada pecah belah umat. Genaerasi ini harus dicoba untuk menengok kebelakang, dimana bumi pertiwi memiliki budaya yang merupakan suplemen merangkai kemajemukan dalam kearifan lokal yang telah yang telah dirajut oleh para pendahulu. Kearifan lokal tersebut sarat akan makna keseimbangan, penghargaan kepada sesama umat manusia maupun pengahargaan kepada alam.

Unsur-unsur pokok modal sosial itu sendiri yaitu kepercayaan (trust), jaringan dan norma. Kepercayaan merupakan dimana masyarakat memiliki sikap saling mempercayai, 
sehingga dengan demikian mereka dapat membangun suatu jaringan sosial dengan prinsip dan modal kesukarelaan (voluntary, kesamaan (equality), kebebasan (freedom) dan keadaban (civity). Adapun norma, merupakan seperangkat aturan yang berlaku dan harus dijalankan secara konsisten oleh masyarakat (Arifin, 2009). Oleh karena itu, pengelolaan secara massif dan dilakukan secara bersinergi terhadap modal sosial. (Arifin, 2009).

Dalam konteks ini menurut Fukuyama mengatakan bahwa modal sosial merupakan seperangkat nilai atau norma informal yang dimiliki bersama oleh individu maupun kelompok yang dapat menjadikan mereka untuk saling bekerjasama (Fukuyama, 1999). Unsurunsur pokok modal sosial itu sendiri yaitu kepercayaan (trust), jaringan dan norma. Kepercayaan merupakan dimana masyarakat memiliki sikap saling mempercayai, sehingga dengan demikian mereka dapat membangun suatu jaringan sosial dengan prinsip dan modal kesukarelaan (voluntary, kesamaan (equality), kebebasan (freedom) dan keadaban (civity). Adapun norma, merupakan seperangkat aturan yang berlaku dan harus dijalankan secara konsisten oleh masyarakat (Arifin, 2009). Oleh karena itu, pengelolaan secara massif dan dilakukan secara bersinergi terhadap modal sosial. (Arifin, 2009). Dimana kearifan lokal adalah segala bentuk kebijaksanaan yang didasari oleh nilainilai kebaikan yang dipercaya, diterapkan dan senantiasa dijaga keberlangsungannya dalam kurun waktu yang cukup lama (secara turun temurun) oleh sekelompok orang dalam lingkungan atau wilayah tertentu yang menjadi tempat tinggal mereka. Kearifan lokal tumbuh dan menjadi bagian dari kebudayaan masyarakat itu sendiri, di mana beberapa hal akan berperang penting dalam perkembangannya diantaranya: bahasa, agama, kesenian, taraf pendidikan, masyarakat, perkembangan teknologi dan yang lainnya.

Kearifan lokal merupakan pengetahuan yang dikembangkan oleh para leluhur dalam mensiasati fenomena masyarakat. Pengetahuan tersebut muncul lewat ceritra-ceritra, legenda, nyanyian, ritual atau aturan ataupun hukum setempat. Hal ini menjadikan pengetahuan yang dilakukan dan dikembangkan kemudian dijadikan sebagai budaya. Keanekaragaman budaya tersebut melahirkan kearifan lokal bagi tiap daerah. Dalam kearifan lokal terkandung kearifan budaya lokal. Secara langsung atau tidak langsung budaya memberi pengaruh pada pembentukan kearifan lokal (Dokhi, 2016, p. 15).

Implementasi moderasi beragama di Indonesia ada beberapa hal yang ingin dicapai salah salah satunya penguatan toleransi, baik toleransi sosial, politik, maupun keagamaan. Toleransi merupakan sikap untuk memberikan ruang dan tidak mengganggu hak orang lain berkeyakinan, mengekspresikan keyakinannya, menyampaikan pendapat, meskipun hal tersebut berbeda dengan apa yang kita yakini. Dengan demikian, toleransi mengacu pada sikap terbuka, lapang dada, sukarela, dan kelembutan dalam menerima perbedaan (Ahmad, 2019).

Moderasi Agama berujung kerukunan adalah fondasi bangsa Indonesia. Tanpa kesediaan untuk hidup rukun, masyarakat Indonesia akan terancam disintegrasi. Oleh karena, Indonesia adalah bangsa yang tersusun 
dari beraneka ragam identitas sosial, agama, dan budaya berbasis kearifan lokal. Konsep kearifan lokal sendiri merupakan bagian yang tidak terpisahkan dari nilai luhur yang berkembang di masyarakat. Yang di dalamnya memuat secara komprehensif tentang kesadaran kolektif masyarakat atas kebudayaan dan kebijaksanaan hidup yang diceritakan dan dilaksanakan secara turun temurun. Hal inilah yang diharapkan dapat menjadi alat moderasi khususnya dalam pengembangan dan pengamalan ajaran agama yang lebih toleran. Di dalamnya memuat petuah kesetiakawanan sosial berbasis agama agar terhindar dari konflik atas nama agama (Muslim, 2019). Keragaman bumi Nusantara melahirkan kearifan lokal yang tersebar dari Sabang sampai Merauke dan masing-masing daerah memiliki kekhasan tersendiri. Potensi perekat antara sesama masyarakat akan ditelusuri dalam penelitian ini dimana diharapkan hadir dalam ruh seremoni kearifan lokal tersebut.

Ide cemerlang dari penelitian ini akan memunculkan gagasan yang terilhami dari nilai-nilai kearifan lokal yang tetap terpelihara di masyarakat. Penelitian ini menjadi penting untuk dilaksanakan dengan menyisir lembaga adat, lembaga masyarakat untuk penguatan kearifan lokal. Yang teraflikasi dari kehidupan sehar-hari di masyarakat.

Dari hasil latar belakang di atas maka permasalahan penelitian yang akan diangkat permasalahan pokok yakni bagaimana Kearifan lokal dalam Masyarakat itu Fungsional sebagai pengembangan, pembinaan. Moderasi Agama di Mamuju. Adapun pertanyaan mendasar dalam penelitian adalah: Kearifan lokal apa saja yang terdapat di
Mamuju yang berorientasi pada Moderasi Agama? Bagaimana efektifitas Masossor Manurung dalam membangun iklim Moderasi Agama? Bagaimana strategi pengembangan Kearifan lokal yang mengandung Unsur Moderasi Agama dapat diimplementasikan dalam Kebijakan?.

Tujuan Penelitian ini adalah: Tujuan Umum: untuk mengetahui bagaimana Kearifan lokal di Bumi Manakarra Fungsional sebagai Alat Moderasi Agama di Kawasan Timur Indonesia.

Adapun oprasional konseptual dalam penelitian ini perlu dijelaskan beberapa istilah yakni : 1)Kata "moderasi" sendiri berasal dari bahasa Inggris, moderation, yang artinya adalah sikap sedang atau sikap tidak berlebihan. Jika dikatakan "orang itu bersikap moderat" berarti ia bersikap wajar, biasa-biasa saja dan tidak ekstrim (Tim \& RI, 2012, p. 5). Kata moderasi dengan merujuk kepada pengertian dasarnya baik dari kata aslinya (Inggris) maupun dari Kamus Besar Bahasa Indonesia, adalah mengacu kepada makna perilaku atau perbuatan yang wajar dan tidak menyimpang. Sementara kata moderasi dalam bahasa Arab, paling tidak terdapat tiga trem yang saling berkelindan, yaitu wasat, mizan, dan 'adl (Tim \& RI, 2012).

(2) Kearifan Lokal menurut kamus besar Bahasa Indonesia, kearifan berarti kebijaksanaan, kecendikiaan sebagai sesuatu yang dibutuhkan dalam berinteraksi. Kata lokal, yang berarti tempat atau pada suatu tempat tumbuh, terdapat hidup sesuatu yang mungkin berbeda dengan tempat lain atau terdapat di suatu tempat yang bernilai yang mungkin berlaku setempat atau universal. 
Kajian Relevan yang terkait dengan artikel yaitu Penelitian terbaru yang dilakukan oleh Tim Lektur Khazanah Keagamaan dan Menejmen Organisasi Balai Litbang Agama Makassar tahun 2019 telah melakukan penelitian dengan tema Moderasi Beragama Dalam Tradisi Lisan di Masyarakat yang dilakukan di empat daerah yakni Provinsi Maluku, Sulawesi Selatan, Kalimantan Timur dan Sulawesi Tenggara. Mengagas rekomendasi bahwa tradisi lisan yang dipahami oleh masyarakat setempat mampu merawat harmoni kerukunan anta sesama beragama dan yang berbeda agama disebabkan tradisi lisan tersebut menggunakan Bahasa daerah yang mampu menyentuh sanubari para penuturnya maupun para pendengarnya.

Tulisan terbaru yang dilakukan oleh Idham dengan judul Moderasi dalam Budaya Islam orasi ini menyoroti masalah moderasi Islam Indonesia dalam 20 tahun terakhir dipertanyakan banyak orang dan bahkan dunia internasional. Mereka mempertanyakan mengapa Islam di Indonesia yang telah ratusan tahun berwajah ramah tetapi tiba-tiba berwajah garang. Hal ini tampak dari hadirnya kalangan teroris dan juga kalangan Islam yan intoloren dengan kelompok agama lain, bahkan dengan kalangan Islam sendiri yang tidak sepaham dengan mereka. Moderasi Islam menjadi perhatiannya dalam orasi tersebut. Sikap-sikap moderat Muslim itulah yang membentuk Indonesia yang damai meskipun plural dalam menganut suatu agama. Hilangnya sikap moderat dapat memunculkan benturan-benturan sesama anak bangsa.

Kearifan lokal merupakan pengetahuan yang dikembangkan oleh para leluhur dalam mensiasati fenomena masyarakat. Pengetahuan tersebut muncul lewat ceritra-ceritra, legenda, nyanyian, ritual atau aturan ataupun hukum setempat. Hal ini menjadikan pengetahuan yang dilakukan dan dikembangkan kemudian dijadikan sebagai budaya. Keaneka ragaman budaya tersebut melahirkan kearifan lokal bagi tiap daerah. Dalam kearifan lokal terkandung kearifan budaya lokal. Secara langsung atau tidak langsung budaya memberi pengaruh pada pembentukan kearifan lokal (Dokhi, 2016).

Dalam pandangan Geertz (2000: 170) religi adalah sebuah pengalaman unik yang bermakna, memuat identitas diri, dan kekuatan tertentu. Sebagai sebuah pengalaman, tentu saja religi tak akan lebih dari subyektivitas pelakunya. Dengan kata lain, religi akan berhubungan dengan rasa, tindakan, dan pengalaman nyata yang berbeda-beda satu dengan yang lain. Setiap orang memiliki perasaan dan pengalaman yang berbeda dalam menjalankan religi masing-masing. Bahkan, dalam perkembangan selanjutnya religi sering dipengaruhi oleh hal ihwal di luar dirinya. Aktivitas politik, modernisasi, gender, dan perubahan dunia amat berpengaruh terhadap fenomena religi. Itulah sebabnya, kajian religi boleh sangat luas dan melebar sesuai keperluan.

Bertolak pada buku putih Moderasi Beragama yang diluncurkan oleh Kementerian Agama pada akhir tahun 2019 yang menyebutkan bahwa moderasi adalah komitmen bersama untuk menjaga keseimabangan yang paripurna, di mana setiap warga masyarakat, apa pun suku etnis, budaya, agama, dan pilihan politiknya harus mau saling mendengarkan satu sama lain, serta saling belajar melatih 
kemampuan mengelola dan mengatasi perbedaan diantara mereka. Jadi jelas moderasi beragama sangat erat terkait dengan menjaga kebersamaan dengan memiliki sikap tenggang rasa, sebuah warisan leluhur yang mengajarkan kita untuk saling memahami dan ikut merasakan satu sama lain yang berbeda dengan kita.

Secara etinologis, kearifan (Inggris: wisdom) yaitu kemampuan individu menggunakan akal pikirannya dalam merespon suatu objek, keadaan, peristiwa atau kejadian. Sedangkan lokal, merupakan ruang atau juga tempat terjadinya interaksi. Dengan begitu dapat dipahami bahwa substansi kearifan lokal adalah adalah nilai-nilai dan norma yang berlaku dan diyakini serta menjadi acuan dalam bertindak pada suatu kelompok masyarakat. Oleh karena itu, kearifan lokal merupakan pemberdayaan potensi nilai-nilai yang telah diwariskan oleh para leluhur dan mengandung kebaikan secara arif dan bijak guna kemaslahatan masyarakat sendiri. Selain itu, kearifan lokal dapat juga didefenisikan sebagai suatu kekayaan budaya lokal (baca:bukan dari luar) yang mengandung kebijakan hidup, pandangan hidup (way of life) yang mengakomodasi kebijakan (wisdom) dan kearifan hidup (Ruslan, 2018).

\section{METODE}

Dalam penelitian ini menggunakan metode penelitian deskriptif kualitatif, melalui penelusuran Kearifan Lokal di Masyarakat berkembang yang saling terkait dengan Moderasi Beragama. Pencarian dan penggalian kearifan lokal berfungsi untuk membangun harmoni, kerukunan di tengah perbedaan dan membangun keseimbangan di masyarakat. Analisis diharapkan setelah menginventarisir makna-makna kearifan lokal yang bermuatan moderasi beragama yang diyakini dan tetap dilakukan oleh masyarakat (tokoh adat, tokoh agama, budayawan, ilmuan pemerhati nilai-nilai lokal, dll.), agar hasil wawancara tidak begitu saja dijadikan sebagai alat tunggal dalam analisis data, namun tetap diperlukan elaborasi teoretis dengan nilai-nilai moderasi agama kelak dikondisikan.

Adapun informan dari penelitian ini adalah informan ahli, informan kunci, dan informan biasa. Mereka ini terdiri dari Pemerintah setempat, tokoh agama dan tokoh masyarakat.para akademisi dan lain sebagainya. serta para masyarakat yang ada di lokasi penelitian.

Teknik pengumpulan dan analisis data yang relevan yang diperoleh dari situasi yang alamiah. Penelitian kualitatif adalah penelitian ilmiah dengan yang menyandarkan kebenaran pada sisi kriteria ilmu empiris yang berusaha untuk mengeksplorasi, mendeskripsikan, menjelaskan, dan memprediksi kejadian-kejadian pada setting sosial (Komariah, 2009, p. 25).

Jika di dalamnya terdapat sinkretisme, maka yang terjadi adalah sebuah proses dinamik dan berulang, suatu faktor yang konstan dalam reproduksi kebudayaan, dan bukan hasil yang statis. Pendek kata, sinkretisme merupakan konsep yang mengarah pada "isu akomodasi, kontes, kelayakan, indigenisasi, dan wadah bagi proses antar budaya yang dinamik". Tegasnya dalam kajian budaya religi, peneliti akan memahami religi bukan sematamata agama, melainkan sebagai fenomena kultural. Religi adalah wajah kultural suatu bangsa yang unik. Religi 
adalah dasar keyakinan, sehingga aspek kulturalnya sering mengapung di atasnya. Hal ini merepresentasikan bahwa religi adalah fenomena budaya universal. Religi adalah bagian budaya yang bersifat khas. Budaya dan religi memang sering berbeda dalam praktik dan penerapan keyakinan. Namun demikian keduanya sering banyak titik temu yang menarik diperbincangkan (Muslim, 2019).

Adapun tekhnik yang digunakan yaitu wawancara mendalam dengan informan, studi dokumen dan observasi lapangan. Data yang terkumpul dianalisis dalam tahapan penulisan dan dianalisis ketika direduksi, kemudian disajikan dalam bentuk deskripsi. Dalam analisis data kualitatif dilakukan secara interaktif dan berlangsung terus menerus sampai tuntas, sampai data menjadi jenuh ( Milles and Huberman, 1984). Wawancara dilakukan untuk mendukung fakta-fakta, dari informan kunci untuk mengatasi kesalahan dan mengandalkan sumber-sumber bukti lain untuk mendukung keterangan informan-informan dan menelusuri bukti sehati hati mungkin (Yin, 1996, p. 107).

\section{HASIL DAN PEMBAHASAN Pesan-Pesan Leluhur di Bumi Manakarra}

Dinamika bermasyarakat

Mamuju berpacu ketika daerah didaulat menjadi ibukota Prosvinsi Sulawesi Barat. Daerah ini berpacu seirama dengan pembangunan fisik yang dilakukan oleh pemerintah setempat. Pusat pemerintahan, pertokoan dan keramaian menampakkan identitasnya sebagai ibukota Provinsi. Daerah ini menjadi surga bagi para pendatang, wilayah yang luas, dan lautan yang membentang mengisyratkan denyut nadi perekonomian akan bisa dinikmati oleh para orang-orang yang mau hidup dan menetap di wilayah ini.

Mamuju di era Pemerintahan Suharto menjadi salah satu ikon transmigrasi dari berbagai daerah di Indonesia kemudian di tempatkan di pelosok pedalaman Manakarra. Mereka kemudian menjadi penduduk Mamuju, dan ada juga suku-suku lain yang datang berimigrasi dan mencari penghidupan yang layak. Sebahagian dari mereka yang berani bertaruh hidup sebagai perambah hutan, mengolah lahan yang luas sekarang hidup dalam keadaan mapan. Di samping itu ketika Mamuju didaulat menjadi ibukota Provinsi nasib para pendatang maupun orang-orang lokal semakin cerah. Mereka merasa betah dan hidup menetap di Mamuju tanpa was-was akan terusik.

Menurut I Made Darsana sebagai anggota kepolisian yang bertugas di Mamuju selama 35 tahun mengungkap bahwa perkelahian disebabkan agama hampir-hampir tidak ada kasus yang terjadi di Mamuju. Mereka hidup aman-aman saja antara satu dengan yang lainnya Salah satu hal yang membuat kondisi Mamuju tetap kondisif hingga hari ini adalah beberapa kearifan lokal yang tumbuh dan menjadi pesan-pesan leluhur orang-orang Mamuju kepada generasinya antara lain: Bumi Manakarra bukan milik segelintir orang tetapi milik semua orang. (Wawancara Bapak I Made Darsana Tanggal 20 Februari 2020).

Beberapa kandungan kearifan lokal ataupun pesan leluhur orangorang Mamuju kepada generasinya antara lain : Da muttanggari tuari rupa 
batannna, kenu biring punccana lipana tapi tanggari ri buah nganganna. Jangan memandang akan kusut wajah seseorang, mungkin copmpang camping kain sarungnya tapi lihatlah sifat puji bahasanya. Seo-soe limanna, anka-ngka bittina. Gemulai kaki mengayun derap kaki melangkah tutur budi bahasa itulah mala'bi. Lanto siri disikammungi artinya ada rasa malu maka genggamlh bersama-sama. Ketika ada permasalahan maka di selesaikan secara bersama-sama ataupun dengan musyawarah. Ketika ketidak sepahaman terjadi maka diselesaikan secara musyawarah dan kedamaian senantiasa dijaga (Wawancara Rasyid Kampil 21 Februari 2020).

Sepanjang sejarah sangat jarang kita mendengar dan melihat kekacauan terjadi di Mamuju. Mereka berpikir bahwa penyelesain terbaik adalah rasa untuk saling menahan amarah. Maka ketika wilayah Mamuju didiami oleh para pendatang, maka mereka akan diterima secara baik dan ketika ada permasalahan akan diselesaikan secara musyawarah. Hukum adat Tuo yang di percayai oleh orang-orang lokal Mamuju adalah Aтритиa kita balimbunganna ada' mapiamo'o ta kadake' majappu tuwo mo tammate, mapia takadake' Filosopinya ketika kita melihat bumbungan rumah adat maka yang baiklah di lakukan karena hidup untuk menamam kebaikan dan kebaikan itu tidak akan mati ataupun rusak. Niwatta bitti karambu, tatttapa dibitti boe, niwatta dikakii boe tatappa dikaki manu, niwattadi kaki manu tattapa di barang-barang. Artinya ketika kita parangi kaki sang kerbau maka akan mengenai kaki babi, ketika diparangi kaki babi maka mengenai kaki ayam, diparangi kaki ayam maka terkena barang-barang. Segala sesuatu terjadi maka senantiasa menjaga kehidupan jiwa sesama manusia hukum di tegakan berdasarkan kehidupan untuk saling menegakan kebenaran tanpa ada hukum menghilangkan nyawa sesesorang. Ketika permasalahan terjadi berupa perkelahian sesama manusia maka akan senantiasa menjaganya jika sudah terlanjur terjadi maka penyelesaiannya bukan dengan hukum parang tetapi di kenai denda berupa harta benda. Ketika seseorang membunuh tidak boleh membunuhnya juga tetapi hukumannya adalah ganjaran berupa tebusan harta benda. Berilah kesempatan kepada sang pembunuh untuk bertobat. Paling tidak diberikan ganjaran yang setimpal berupa denda harta benda. Hukum darah tidak dibalas dengan darah, tetapi senantiasa diarahkan kepada denda kepada si pelaku. Jiwa manusia sangat dihargai dalam hukum tuo ini. Tanpa memandang dari mana pun mereka dan agama apapun yang mereka anut hukum tuo ini tetap berlaku. (Wawancara Bapak Rasyid Kampil 22 Februari 2020).

Begitupun falsafah "Ampue muinummmo wae randdannna Maтuju, majappu to Mamuju moko (wawancara Bapak Rasyid Kampil, 23 Februari 2020).

Ungkapan ini sangat filosofis. Orang Mandar sangat mudah menerima orang lain dengan cara sederhana. Orang luar yang sudah meminum air di tanah Mandar. Tentu sikap budaya yang moderat ini menjadi modal yang sangat penting dalam mengembangkan pergaulan antar etnis. Sikap moderasi dalam berbagai aspek, menjadikan keterbukaan dan penerimaan orang Mandar terhadap orang luar sudah terjadi sejak dahulu kala (Idham, 2019, p. 20). Di Bumi Manakarra 
kemajemukan sudah terpola sejak zaman dahulu kala, salah satunya peristiwa perkawinan antara putra mahkota kerajaan Mamuju dan Putri Bali Maha Dewi terjadi. Dari hasil perkawinan ini melahirkan anak yang bernama Lasalaga. Kekerabatan dalam pertalian darah pun terjadi. Dalam kurun waktu cukup lama, orang-orang Bali sudah berada di Mamuju dan beranak pinak. Demikian pun di masa era Suharto Ketika transmigrasi digalakkan orang Bali dengan mudahnya hidup dan menetap di wilayah ini.

Menurut Bapak Aryandi pegawai Dinas Kebudayaan mencoba memahami jiwa dan watak orang lokal Mamuju menuturkan:

Bahwa di zaman dahulu sebahagian besar kami memiliki watak yang lembut dan halus termasuk orang-orang yang mendiami wilayah Mamuju yang dan mendiami wilayah pegunungan. Tetapi kadang juga karena berada di wilayah gunung yang panas maka sebahagian dari kami mudah terbawa emosi mempengaruhi suhu badan dan watak yang kadang kala keras kepala. Beberapa faktor yang membuat orang-orang pegunungan keras karena mereka sangat jarang berinteraksi dengan dunia luar. Tetapi kami dituntun oleh suatu pesan-pesan leluhur orang tua kami untuk senantiasa mendengar pesan tersebut dan mengaplikasikannya. Kami juga senang dengan orang-orang yang mau bersahabat dengan kami. Maka ketika ada orang baru mereka akan senantiasa waspada. Maka ketika orang-orang pendatang datang dengan cara yang santun maka penduduk lokal akan mempelajari watak sang pendatang. Dan ketika para pendatang tersebut mampu berinteraksi secara baik maka sifat asli orang Mamuju yang lembut akan menerima mereka dengan cara yang ramah. (Wawancara Bapak Tri 20 Februari 2020).

Masossor Manurung di wilayah Sulawesi Barat sangatlah beragam dan mempunyai ciri khas dan ceritra tersendiri. Seperti daerah Sendana, Majene, dan Pamboang, dan daerah lainnya. Dalam dialek bahasa Mamuju Masossor berasal dari kata sosssor artinya membersihkan dan menajamkan, serta dimaknai suatu upaya memberikan penajaman kepada suatu benda khususnya keris, parang dan lain-lain . Menurut morfologi bahasa Mamuju ketika suatu kata berfonem huruf s dilekati oleh efik ma maka terbentukla kata Manossor. Apabila suatu kata berfonem bahasa $\mathrm{s}$ dilekati oleh afik ma maka terjadi proses penambahan huruf $\mathbf{m}$ terbentuklah kata manossor. Untuk memberikan penajaman makna pada istilah sossor itu sehinggga terbentuklah kata Masossor. Dan inilah bahasa dialek asli orang Mamuju wawancara Rasyid Kampil 22 Februari 2020.

Manurung adalah penamaan sebuah keris yang yang mempunyai kesaktian, Manurung diartikan sebagai suatu benda (keris puasaka) yang diyakini memiliki kesaktian, karena keunikan dan keberadaannya dilahirkan dari rahim seorang ibu yang memiliki kembaran bernama Lasalaga yang bergelar Tomatindo di Puasanna. Menurut sejarah Bali Lasalaga ketika sampai di Mamuju beralih memeluk 
agama Islam Wawancara Bapak Aryandi 24 Februari 2020)

Dengan demikan jika di depan kata ini (manurung) ditambahkan kata masossor, maka terbentuklah sebuah kata atau istilah Masossor Manurung. Masossor Manurung adalah upacara ritual yang dilaksanakan oleh orang Mamuju yang melibatkan orang-orang adat dan khalayak dengan menggunakan serangkaian seremoni adat yang telah ditentukan. Pada masa silam sekitar abad XVII masehi. Pada masa kerajaan Mamuju ritual Masossor Manurung dilakukan dan dikenal oleh masyarakat Mamuju. Sekitar abad XVII pada masa pemerintahan Raja Pammmarica, masyarakat Mamuju mengalami suatu masa paceklik, dimana seluruh hasil bumi berupa padi, buah,buahan dan hasil laut berupa ikan dan lainnya tidak menghasilkan seperti apa yang diharapkan oleh penduduk dikala itu.

Orang-orang Mamuju menyebut daerah mereka sebagai bumi Manakarra yang artinya Pusaka bertuah. Perpaduan dua istilah yang berbeda tetapi memiliki satu makna yang artinya pusaka atau warisan, Karra artinya bertuah. Salah satu hal mengapa Mamuju di sebut Makarra karena memiliki pusaka yaitu keris Lasalaga yang di keramatkan oleh orang-orang Mamuju. Di samping itu Manakarra sebagai arti dari pusaka atau warisan bertuah adalah daerah/ tanah yang diwariskan oleh leluhur orang-orang Mamuju memiliki daerah tanah yang subur. Lautmu yang bening membiru meliuk-liuk sepanjang masa. Menyimpan aneka sumber hayati yang tersimpan di sela-sela karang-karang. Wilayah lautan dan daratan adalah pusaka bertuah yang diwarikan oleh leluhur mereka yang harus dijaga keseimbangan alamnya serta seluruh masyarakat yang mendiaminya hidup dalam kedamaian tanpa membedakan agama dan suku.

Dalam alam pikiran orang lokal Mandar bahwa konsep perkawinan adalah hubungan darah berantai yang menghubungkan dari satu generasi kegenerasi berikutnya. Hal tersebut melahirkan konsep kemakmuran, regenerasi, saling membantu, dan saling menghargai. Konsep ini mereka pegang tanpa membedakan suku, agama dan strata sosial. Dengan terjadinya perkawinan itu maka kedua belah pihak akan terjadi sebuah budaya sirondorondoi (saling membantu), siajumai (saling menguatkan), siamasei (saling mengasihi), siasayanggi (saling menyayangi), siannang pa'mai (saling mengasihi yang mendalam), siannnang siri' (saling menutupkan kekurangan), sipakkasi-asiang (bersama dalam penederitaan), sibaliparri (saling bantu membantu), hal tersebut menjadi dasar dalam membangun hubungan silaturahmi dan kekerabatan diantara mereka (Ismail, n.d., p. 266).

Dalam proses pergulatan sejarah inilah yang membuat orang-orang Bali mempunyai ikatan darah, serta emosional dengan orang Mamuju. Di era tahun 40 an sudah ada beberapa orang Bali hidup dan menetap di Mamuju. Secara geografis lautan wilayah Bali bisa ditempuh dalam tiga sampai empat hari melalui lautan. Pelaut ulung dari Mamuju sering berlayar ke pulau Bali dalam rangka menjual penyu. Hubungan orang Bali dengan orang-orang Mamuju sangatlah kental terlebih lagi dengan ikatan leluhur mereka lewat perkawinan. Maka di era tahun 1940-an beberepa orang Bali sudah hidup dan menetap di Mamuju salah satu pengaruhnya adalah 
nama-nama orang-orang Mamuju ada pengaruh nama Bali seperti Gusti, dan Ma dewi dan yang lainnya.

Prosesi penyeleggaraan upacara Masossor Manurung diawali dengan penjemputan benda pusaka kerajaan (keris pusaka) yang akan disucikan (disossor) bersama dengan air pensuciannya. Benda pusaka tersebut berada di rumah kediaman salah seorang turunan raja Mamuju yang memelihara dan merawat benda pusaka tersebut.

Pusaka tersebut disucikan atau disossor diarea yang telah ditentukan, sebelum disossor benda tersebut diletakan di atas meja persemayaman yang telah disediakan sambil menunggu prosesi pensuciannya. Tahapan dalam proses ini sangatlah disakralkan, maka sangat terbatas orang-orang yang dapat melihat benda tersebut. Yang bisa melihatnya hanyalah turunan raja Mamuju dan turunan raja Badung, serta pemangku adat (gala'gar pitu), tokoh adat Bali serta beberapa pejabat dari unsur pemerintahan.

Proses pembersihan dan pensucian benda tersebut dilakukan oleh Tokayang di Padang di dampingi oleh salah seorang dari tujuh pemangku adat setempat, mengambil pusaka tersebut dari meja persemayamannya dan melepas kain yang membungkusnya. Denga khidmat di panjatkan doa kemudian benda tersebut dibersihkan/disucikan secara hati-hati dengan air kembang yang telah dicampur beragam kembang. Pembersihan dan pensucian dilakukan oleh Tokayang di Padang bersama Pa'bicara. Setelah Prosesi ini selesai maka benda tersebut diserahkan kepada pandita Bali yang hadir dalam acara tersebut. Pandita Bali ini kemudian meletakkan benda pusaka tersebut di atas meja persemayamannya selama 1 jam.

Air bekas pembersihan benda ini menjadi incaran khalayak ramai untuk diambil. Kepercayaan penuh unsur sakral yang dimitoskan antara lain airnya bisa dijadikan sebagai mempermudah jodoh dan memperbanyak rezeki. Tetapi apapun unsur sakral di dalam air tersebut sebagai umat yang beragama rezeki dan jodoh hanya Tuhanlah yang menentukan.

Menurut I Made Darsana bahwa dalam kepercayaan orang Hindu ritual Masossor Manurung adalah bentuk penghormatan kepada benda-benda mati antara lain Keris. Benda-benda mati pun di hormati seperti keris benda tajam yang di doakan kepada Tuhan berfungsi sebagaimana mestinya. Bukan untuk membunuh sesama manusia. Seperti Masossor Manurung bagi kami bukan memuja keris tetapi untuk memberikan lambang bahwa keris tersebut adalah benda tajam yang harus digunakan sebagaimana mestinya. Dalam hakekatnya benda keris ini disossor ditajamkan kembali ingatan anak-anak turunanya bahwa mereka ada ikatan persaudaraan oleh leluhur mereka. Kami memuja Tuhan Syang Widi Wahsa. Memohon kepadanya Dewa Syang Widi Wasa supaya pusaka yang ada di Mamuju ini berfungsi sebagaimana mestinya. Keris itu bukan kami sembah karena itu benda mati, karena di masyarakat Bali ada hari Raya buat benda benda tajam yang disebut Tumpa lanep untuk menghormati benda-benda tajam. Dengan tujuan berfungsi sebagaimana mestinya. Keris itu hanyalah symbol untuk disakralkan kembali benda itu dalam artian persaudaraan itu diagungkan dan dijaga oleh generasi sekarang ini. 


\section{Efektifitas Masossor Manurung Membangun Iklim Moderasi Beragama.}

Pada dasarnya ritual ini dimaksudkan untuk menghilangkan kesulitan dan situasi yang tidak menentu di masa silam (Ansaar, 2006, p. 48). Di masa sekarang ini upacara ritual Masossor Manurung menjadi event penting untuk konsolidasi tentang pentingnya nilai luhur yang tersirat dalam kearifan lokal yang ditanamkan oleh leluhur. Dan memberi pengaruh efektif membangun potensi moderasi beragama tanpa memandang perbedaan agama dan suku. Kesulitan tentang perbedaan yang melingkupi kemajemukan kadang menjadi bias perbedaan yang saling mencurigai dan menjadi kekacauan suatu wilayah. Tetapi leluhur orang-orang Manakarra sangat jeli melihat kondisi di masa depan. Mereka seakan sadar ratusan tahun kemudian anak cucunya akan, mengalami suatu kesulitan di tengah kemajemukan agama, suku dan strata sosial.

Moderasi beragama dalam kearifan lokal merupakan suplemen yang mengakar yang mampu menyentuh masyarakat Mamuju. Masossor Manurung menjadi event penting konsilidasi tetang pentingnya nilai luhur yang tersirat dalam kearifan lokal yang ditanamkan oleh leluhur mereka efektif membangun kebersamaan tanpa memandang perbedaan agama, suku dan strata sosial ataupun yang lainnya.

Dalam masyarakat Mandar secara luas termasukk Mandar Mamuju, bahwa melalui ikatan kekerabatan dapat dilihat berbagai aspek hidup dan kehidupan manusia saling terpaut. Kekerabatan membangkitkan perasaan sekerabat yang mendalam bagi mereka.
Ia dirasakan sebagai suatu ikatan sosial yang mendasari kebersamaan, senasib dan berbagai hal yang menyangkut masalah suka dan duka. Bahkan seseorang akan terkait secara erat dengan anggota masyarakat lainnya. Berdasarkan hal tersebut bagi orangorang Mandar secara luas kekerabatan mempunyai dua makna. Kekerabatan tidak hanya diartikan dalam makna harfiah berupa keterkaitan seseorang dengan orang lain karena hubungan darah dan hubungan perkawinan. Namun juga bermakna simbolis yang diperluas dalam keterkaitan antar individu dengan yang lain dalam batas daerah, suku bangsa, dan bahkan ideologi (Ismail, n.d., p. 259). Dengan adanya sebuah keris yang disimpan oleh dewan adat Mamuju mempunyai makna simbolis bahwa ikatan kekerabatan mereka dengan pihak luar kerajaan Badung haruslah terus disambung tanpa memandang perbedaan Agama dan suku ataupun yang lainnya. Hal inilah yang mendasari penelusuran yang dilakukan oleh orang-orang Mamuju untuk menyambung tali kekerabatan dimasa silam yang telah dilakukan oleh leluhur mereka beratus tahun yang silam. Tentang ceritra yang tersebar tentang perkawinan antara putri Bali dan putra Mahkota raja Mamuju dikisahkan dari mulut ke mulut. Orang-orang tua akan selalu menceritrakan hal tersebut secara turun temurun dan sangat memperhatikan dan selalu membicarakan hubungan seseorang dengan orang lain khususnya bila terjadi perkawinan. Kadangkala setiap rumah tua, memiliki silsilah yang disimpan oleh orang yang dituakan dengan menyimpan sila-sila (silsilah) keluarga dengan baik. Kadang diacara keluarga akan dibuka silsilah untuk menjelaskan 
hubungan mereka sanak family yang lain. Maka beberapa dewan adat dan pemerintah daerah Kota Mamuju sekitar tahun 2000-an mereka menghadap dewan adat Kerajaan Badung. Melalui kunjumgan tersebut beberapa utusan dari Bali membalas kunjungan tersebut dengan hadir di Mamuju.

Beberapa pemukiman penduduk yang menjadi miniatur beragam corak kemajemukan hadir dan hidup secara alamiah di berbagai pelosok daerah Mamuju baik di kota maupun di penjuru pedalaman bumi Manakarra. Dan menjadikan ritual Masossor Manurung sebagai alat pemersatu akan perbedaan suku, strata sosia maupun agama. Beberapa daerah di bumi Manakarra yang didiami oleh beragam suku dan agama antara lain;

Desa Toabo Kabupaten Mamuju Kecamatan Papalang sebuah pemukiman yang dihuni berbagai etnis dan agama yang berbeda. Suku Mandar, Bali, Jawa, Lombok, Makassar dan Bugis. Suku-suku ini menganut agama yang berbeda pula, keanekaragaman ini mereka disatukan oleh suatu keragaman kearifan lokal yang mereka yakini sebagai pandangan hidup dalam berinteraksi. Hawa kedamaian terpancar dari pemukiman ini dengan bangganya tempat-tempat ibadah seperti Pura, Gereja, dan Masjid berdiri dengan megahnya. Sekitar 700 kepala keluarga menghuni desa Toabo. FKUB sering datang mengunjungi kampung ini memberikan sosialisasi para pemuka agama sering berembuk untuk membangun damai di kampung ini. Falsafah hiduplah yang mempertemukan berbagai komunitas ini untuk saling memberikan keseimbangan hidup, di tengah perbedaan yang ada salah satu falsafah hidup yang menjadi kearifan lokal yaitu: Ajaran Hidup orang Hindu dalam kitab sucinya Begawad Gita, di dalamnya memuat selaku ciptaan Tuhan menghargai sesama manusia. Tri Hita Karana adalah tiga pesan-pesan moral berisi 3 tiga tingkah laku yang baik. Dalam hidup ini wajib melakukan: Dalam Tri Kayu Parisude :1) Berkata Baik. 2). Berbuat Baik. 3). Berpikir Baik.

Kearifan lokal ini termaktub dalam kitab suci dan ditanamkan oleh leluhur terdahulu hingga kegenerasi mereka secara intens untuk dilakukan. Dan biasanya Tri Kayu Parisude di ajarkan dalam Pasraman di didik di dalam Pura. (semacam pesantren). Pasraman ini di motori oleh Kepala Desa beragama Islam. Toleransi beragama sangat dijunjung tingga oleh sang Kepala Desa dan tidak ada yang dianak tirikan semua penduduk dilayani dan diayomi secara adil, bantuan desa berupa alat tulis menulis dan meja kursi diperuntukkan bagi proses belajar mengajar di Pasraman tersebut.

Ketika menetap di daerah tersebut Janggo Saide menamam pohon kelapa, dan tanama lainnya dan ketika selesai perahu dibuatnya maka ia akan berpindah tempat lain. Dalam ingatan bapak La Hade mengatakan "Атрие muinummmo wae randdannna Maтијu, majappu to Maтuju moko Ketika sudah meminum air jernihnya orang Mamuju maka akan menjadi orang Mamujulah kamu. Pesan ini terus diingat oleh La Hade sehingga ia bisa bertahan hidup mengelola hutan belantara Toabo. Hingga beberapa suku lain bertangan meramaikan desa tersebut dan ditunjang pula Toabo menjadi tempat para transmigran untuk mengolah lahan yang masih luas (Wawancara Bapak Arif Usman Ketua RT Toabo tanggal 1 Maret 2020). 
Hasil kebun pak La Hade sering membagikannya kepada mereka para transmigran. Hasil panen berupa jagung, kelapa dan lain-lain, akan diberikan untuk mereka makan. Jalinan harmonis tersebut adalah pondasi awal hubungan diantara mereka yang beda etnis, agama, dan latar belakang sosial. Dan ini diteruskan oleh generasi selanjutnya yang mukim di tempat tersebut. Acara-acara sosial menjadi tempat para pendatang ini untuk berinteraksi. Seperti pesta panen, acara gotong royong membersihakan kampung, ataupun acara kematian warga mereka akan datang berbodongbondong. Mereka saling mengenal antara satu dengan yang lain walaupun jarak rumah mereka berjauhan. Jadi ketika ada riak-riak kecil seperti perkelahian antar pemuda ataupun perselisihan karena batas tanah akan diselesaikan secara kekeluargaan. Demikian pun persoalan kehidupan beragama tidak hampir hampir tidak ada konflik. Karena setiap ada masalah pasti di mediasi diselesaikan secara baik.

Dewasa ini Imam Masjid puang Solong orang Pankep, hubungannya dengan bapak pendeta Kristen dan pak Putu selaku Pandita agama Hindu sangat baik. Konflik-konflik kecil antar anak muda saja biasa berkelahi dengan batas tanah para petani tapi semua itu diselesaikan seacara baik oleh para tokoh agama dan pemerintah lewat nasehat kearifan lokal masing-masing. Begitupun ternak babi,akan diusahakan di pindahkan di belakang rumah atau di tempatkan di kebun. Komposisi penduduk beragama Islam yang lebih banyak, kemudian agama Hindu dan agama Kristen Toraja dan Mamasa. Struktur pemukiman diantara mereka sangatlah unik para etnis ini tidak hidup bergerombol dengan sesama agama tetapi mereka hidup secara pariatif berselang seling tempat. Contohnya muslim berdampingan rumah dengan Kristen begitupun Hindu. Adapun tempat ibadah Kristen, Katolik, Pura saling berdampingan dan berhadapan dengan masjid. Sebuah pemandangan kemajemukan ditengah kepadatan penduduk.

Setiap satu tahun di kampung ini akan diadakan pesta panen, seluruh penduduk berkumpul memasak hasil bumi mereka masing-masing kemudian duduk bersama saling tukar menukar makanan. Tidak hanya itu peragaan kesenian masing-masing dimunculkan dari suku Bugis memukul Rebana, Pa, dendang, Hindu tarian-tarian. Dari pihak Kristen bergabung dengan suku Jawa mereka menyanyi. Acara perkawinan sering saling tolon menolong diantara mreka, begitupun ketika ada yang meninggal pasti mereka datang turut berbela sungkawa. Begitupun ketika diadakan perhelatan ritual Masossor Manurung maka penduduk dari desa Toabo akan berbondong-bondong mengikuti acara tersebut. Bagi mereka air suci dari penajaman, pembasuhan keris manurung memberikan berkah karena disertai doa kepada Tuhan akan kesuburan tanah Manakarra. Demikian pun pada acara itu mereka bertemu teman dan keluarga dimana memberi harapan penajaman watak persaudaraan yang harus terus dipupuk di tengah perbedaan yang ada di luar desa dan di lingkungan desa meraka.

Kelurahan Rimuku Kecamatan Mamuju merupakan tempat orangorang Bali hidup di wilayah kota Mamuju. Terletak di belakang Kantor kepolisian Kota Mamuju. Tidak ada yang hidup secara berkelompok mereka berbaur dengan masyarakat pada 
umunya di Kelurahan Rimuku Kecamatan Mamuju. Tapi pada umumnya mereka tidak hidup secara kolektif atau berkelompok tetapi selalu berbaur dengan pemukiman penduduk. Di kota Mamuju mereka juga ada yang di daerah Rangas. Maka khusus untuk di kota mereka tidak memelihara ternak seperti babi, dan memilih ternak lain untuk dipelihara. Ini adalah penghargaan mereka kepada umat lain. Penghargaan kepada sesama tetangga yang muslim, sangatlah tinggi. Mereka mengetahui binatang Babi bagi saudara mereka yang beragama Islam adalah haram. Dan mereka memilih untuk tidak memelihara ternak karena pemukiman penduduk yang cukup padat, maka kotoran binatang akan membuat udara tercemar. Maka secara alamiah mereka pun berbaur satu dengan yang lainnya. Mereka sadar jika merantau dimana tanah itu bisa ditempati dan di beli maka di situlah mereka menetap begitupun warga lainnya mereka hidup berdampingan di tengah kemajemukan yang ada.

Ajaran Hindu dalam bahasa Sangsekerta di kitab Weda berbunyi :Wasudewa Kutum Bakam yang maknanya bahwa kita semua bersaudara tanpa memandang suku dan latar belakang manusia tersebut. Begitupun Adiqum (Falsafah Hidup) Tatwam Masih yang berbunyi : Kamu adalah saja dan saya adalah kamu. Falsafah inilah yang mendasari mereka dalam berbuat, bertingkah laku dalam kehidupan sesama manusia. Jika kamu berbuat maka jangan saling menyakiti karena ketika kamu menyakiti orang lain sama saja kamu menyakiti diri sendiri. Begitupun sebaliknya ketika kamu menyayangi dan menghormati orang lain sama halnya kamu menyayangi diri sendiri. Karena tidak akan diam sebuah hukuman dia akan berjalan hukuman itu dengan sendirinya. Ini adalah dasar dan falsafah orang yang beragama Hindu dalam bermasyarakat (Wawancara Bapak Wayan Buja, tanggal 24 Februari).

Ajaran seperti ini terus dikumandangkan di dalam setiap persembahyagan. Maka umat Hindu ketika ada percikkan yang membuat mereka marah, akan senantiasa menahan diri, dan tidak menyukai keributan. Kalaupun tidak bisa dihindari maka mereka tidak pernah memulai perselisihan tersebut. Setiap masalah biasanya karena faktor luar saja. Para pemuka agama selalu mengumandangkan kedamaian. Dan menyelesaikan ketidak sepahaman dengan jalan musyawarah dan kekeluargaan. Perselisihan itu tidak pernah berakhir diranah hukum, tetapi diselesaikan secepatnya di lingkungan masyarakat dan keluarga.

Daerah Tommo Begitu luas mereka menyebutnya Tommo 1,2,3,4,5,6,7,8 pemukiman yang hidup dengan perbedaan suku agama yang saling membaur antara satu dengan yang lainnya. Jumlah Kepala Keluarga sekitar 747 kepala keluarga, dengan pemeluk agama terbanyak adalah agama Hindu, sekitar 330 kepala keluarga, sisanya adalah Islam, Kristen dan Katolik.

Desa ini terbentuki era Suharto, sekitar tahun 1982-1983 ketika transmigrasi digalakkan. Para transmigrasi tersebut digelombang pertama sekitar 40 Kepala Keluarga yang di tempatkan di desa Kuo, tetapi karena tidak betah di desa tersebut akhirnya pindah ke daerah Tommo. Kemudian datang lagi 400 Kepala keluarga. Mereka berasal dari daerah Badung, Jembrana, Buleleng, dan 
Gianyar, serta Bali Nusa Dua. Dulu daerah ini hanyalah hutan belantara di sini tumbuh banyak pohon yang tinggi menjulang kemudian berduri dimana orang lokal disini yang pertama hidup menyebutnya pohon Tommo, pohon sejenis pohon kelapa atau pohon pinang tetapi berduri. Kemudian mereka menamakan daerah tersebut sebagai desa Tommo. Dan sekarang pohon tersebut sangat jarang tumbuh karena diganti oleh perkebunan kelapa sawit.

Penduduk asli hidup di kampung sebelah bernama desa Tamemongga berjarak sekitar 5 kilo dari kantor desa Tommo. Mereka adalah penduduk lokal Mamuju, di sebelahnya lagi ada desa Kalepu dengan penduduknya suku Bugis. Beragam suku ada di pemukiman Tommo ini ada suku Bugis, Mandar Mamuju, Mamuju, Bugis, Jawa, Bali, Sunda, dan Toraja. Dan semua suku saling menjaga kerukunan antar suku dan agama. Falsafah hidup ruku ajaran Tatm masih menjadi modal dasar orang Bali dalam bermasyarakat, begitupun orang Mamuju lokal menganggap mereka sebagai saudara sendiri. Dahulu ketika pertama kali menginjakkan kaki di desa Tommo, penduduk transmigran khususnya orang Bali yang ingin mengadakan ritual persembahyangan, memerlukan buah kelapa dan janur kuning mereka akan meminta kepada orang-orang lokal Mamuju. Dengan penuh keramahan penduduk lokal tersebut memberikan apa yang dibutuhkan mereka dalam acara persembahyangan. Awal pertemuan dan interaksi ini melahirkan ketulusan diantara mereka untuk hidup secara damai.

\section{Implementasi Kebijakan Kearifan Lokal Yang Mengandung Moderasi Beragama}

Implementasi kebijakan yang sedang digalakkan oleh Pemerintah Daerah setempat adalah event ritual Masossor Manurung mempunyai bias yang besar dalam merakit, merangkai dan merangkul seluruh elemen masyarakat tanpa pemandang suku dan agama serta latar belakang sosial kultural mereka. Ritual Masossor Manurung merupaka seremoni menajamkan sebuah keris yang disimbolkan sebagai tetesan darah putri Bali dan raja Mamuju. Tetapi dibalik itu tersimpan pengetahuan bahwa leluhur mereka menitipkan keris yang setiap tahunnya ditajamkan sama dengan menajamkan memori ingatan generasi sekarang bahwa pentingnya pesaudaraan itu terus ditajamkan, maka beberapa kebijakan yang ingin ditelurkan guna kearifan lokal dalam moderasi beragama yang melibatkan berbagai unsur perlu diperhatikan.

Begitupun daerah Mamuju sebagai wilayah ibukota Provinsi Sulawesi Barat untuk saat ini menjadi miniatur bebagai suku-suku pendatang datang dan menetap di bumi Manakarra ini. Kedatangan mereka tidak mengusik para penduduk lokal karena leluhur mereka telah mengajarkan beberapa falsafah hidup tentang pentingnya memandang manusia yang berbeda dengan mereka adalah hal yang alamiah. Pesan-pesan leluhur orang-orang Mamuju seharusnya ditindak lanjuti dalam bentuk memasukkannya dalan kurikulum pelajaran muatan lokal. Ataupun dijadikan Pendidikan moral berbasis agama.

Persaksian Bapak Rasyid Kampil tetang penghargaan beragama di Mamuju adalah Keluarga saya dari 
Kalumpang Ulusalu banyak yang beragama Kristen. Maka di setiap rumah-rumah mereka di Kalumpang disediakan Sajadah bagi kerabat mereka yang bertandang ke rumahnya. Mau makan ayam silahkan potong sendiri, bahkan pernah terjadi seorang anak Imam di Kalumpang kawin dengan orang Kristen dia beralih agama. Kalua lelakinya beragama Islam wanitanya beragama lain pada umumnya akan mengikuti agama sang lelaki. Begitu pun di agama Hindu. Para wanita yang beragama Hindu akan senantiasa ikut agama sang lelaki. Begitupun sebaliknya.

Sejalan dengan apa yang dikatakan oleh I Made Sukanayasa, aturan secara tertulis tidak ada tetapi aturan secara adat dilakukan jika seorang Laki-laki Hindu menikah dengan agama lain maka ia akan berusaha tetap beragama Hindu. Tetapi kalua wanita Bali menikah dengan agama lain maka bisa saja ia mengikuti agama suaminya. Disebakan hukum agama Bali mengharuskan laki laki sebagai pemimpin dan hak waris lebih banyak diterima oleh laki lakinya sedangkan perempuan pembagian warisan sangatlah sedikit $20 \%$ Saja mereka dapat jika sampai keluar dari agamanya maka mereka hampir tidak memiliki hak warisan tetapi zaman sekarang ini para orang tua sudah memberikan hamir sama pembagiannya untuk anak laki dan perempuannya.

Leluhur garis keturunan diambil dari garis keturunan sang laki laki dan sebahagian penyembahanpenyembahan kepada Tuhannya di pimpin oleh lelaki, makanya dia harus teguh dalam agamanya.

Di kalangan pemeluk Agama Hindu untuk memberikan pelajaran kepada anak-anak maka dibentuk pasraman belajar tentang ritual, makna, pembacaan kitab dan yang lainnya. Proses belajar mengajarnya yaitu kitabnya dibaca kemudian diberi makna. Pasraman untuk kota Mamuju bernama Pasraman Manakarra berlokasi di samping stadion. Belajar mengajar dilakukan di hari Minggu, cara tersebut ditempuh dengan mengumpulkan anak anak tersebut di luar jadwal sekolah mereka. Mereka yang tidak mendapat pelajaran agama di sekolah akan diberikan pelajaran agama di Pasraman tersebut.

Pembinaan umat pun dilakukan oleh para pegawai Pembimas Hindu Agama Kanwil Kemenag mereka hadir memberikan pelayanan kepada umatnya. Salah satunya pembinaan keluarga Sukinah yang dilakukan oleh para penyuluh agama Hindu. Begitupun alat tulis menulis disediakan bagi anakanak yang belajar di Pasraman. Kendalanya sekarang inii guru untuk agama Hindu untuk kota Mamuju hanya dua orang saja. Dengan alasan perbandingan jika muridnya sepuluh siswa dan siswi maka gurunya hanya satu orang saja, dengan diperbantukan guru-guru honorer. Jika program kearifan lokal yang memiliki unsur moderasi beragama di masukan kedalam program keluarga Sukinah di Hindu dan keluarga Sakinah di di Islam begitupun di pemeluk agama Kristen. Dilakukan dengan mengumpulkan bebagai pesan-pesan leluhur, kemudian disosialisasikan oleh para penyuluh kementerian agama. Dengan mengacu kepada pesan-pesan leluhur orangorang Mamuju yang sarat akan nilai kearifan lokal yang mengandung moderasi beragama.

\begin{tabular}{lcr}
\multicolumn{1}{c}{ Ritual } & Masossor & Manurung \\
berbagai & elemen & masyarakat \\
berpartisipasi & mulai dari persiapan
\end{tabular}


hingga acara upacara tersebut terlaksana. Mereka semua merasa memiliki dan menjadi bagian dari apa yang tersirat dalam ritual tersebut, yaitu mengenang, menghayati dan menajamkan memori sejarah leluhur mereka yang telah mengikat tali perkawinan dengan suku diluar pulau Sulawesi. Ketika para tetua adat duduk saling berdampingan tanpa membedakan suku dan agama menjadi panutan bagi khalayak ramai.

Momen ini pula mempertemukan mereka dari berbagai wilayah di pelosok kota maupun pedalaman Mamuju untuk saling mengenal antara satu dengan yang lainnya. Tanratu pattana Bali bahwa Mamuju itu kerisnya dan Bali itu adalah sarungnya. Legenda tentang perkawinan Raja Mamuju dengan putri Bali tetap diingat oleh Masyarakat Mamuju. Melalui ritual tersebut mereka paham bahwa Mamuju dan Bali mempunyai hubungan darah. Orangorang tua mereka sebahagian tidak pernah menceritrakan tentang asal usul ritual tersebut dilakukan. Maka ketika acara ini menjadi hal yang rutin dilakukan setiap dua tahun yang bertepatan dengan hari jadi kota Mamuju mendai momen penajamkan ingatan para generasi sekarang. Hal tersebut punya kesan tersendiri dan pembelajaran bahwa betapa majemuknya wilayah ini betapa bedanya kita dengan suku lain tetapi toh mereka bisa duduk damai semua. Dan ritual ini dijadikan sebagai pesona Indonesia buat pancingan wisatawan masuk dan mengunjungi Mamuju. Di samping upacara pemerintah desa yang terkecilpun ikut serta berpartisipasi guna lancarnya acara ritual tersebut.

\section{PENUTUP}

Beberapa kerarifan lokal yang berorientasi pada moderasi beragama teraflikasi dalam pesan leluhur terangkum dalam, falsafah-falsafah hidup dan ritual yang sarat akan makna penghormatan sesama manusia tanpa memadang suku dan agama. Salah satunya ritual Masossor Manurung merupakan fenomena budaya. Dimana aspek religi mengapung diatasnya. Hal ini direpsentasekan dalam fenomena perpaduan dua suku Mandar dan suku Bali walaupun berbeda keyakinan agama. Diikat dalam suatu fenomena kultural budaya. Namun demikian keduanya mempertemukan diri dalam wadah ritual Masossor Manurung.

Efektifitas kearifan lokal membangun iklim moderasi beragama dimana Masossor Manurung terdapat keseimbangan keadilan di dalam kemajemukan beragama dan bersuku. Hal ini merupakan suplemen yang mengakar yang mampu menyentuh berbagai elemen masyarakat di kota maupun pedalaman Mamuju.

Implementasi srategi kebijakan yang sedang digalakkan oleh Pemerintah Daerah setempat adalah event ritual Masossor Manurung mempunyai bias yang besar dalam merakit, merangkai dan merangkul seluruh elemen masyarakat. Ritual Masossor Manurung merupakan seremoni menajamkan sebuah keris yang disimbolkan sebagai tetesan darah putri Bali dan putra mahkota Mamuju. Tetapi dibalik itu tersimpan pesan abstrak, bahwa leluhur mereka menitipkan keris yang setiap tahunnya ditajamkan sama dengan menajamkan memori ingatan generasi sekarang bahwa pentingnya pesaudaraan itu terus dibina. 
Diperlukan penguatan lembaga adat dan pemerintah daerah yang bersinergi dengan Kementerian Agama dalam membangun Moderasi beragama yang dibingkai oleh kearifan lokal.

Diperlukan modifikasi penerapan moderasi beragama dalam kearifan lokal dengan melibatkan, para penyuluh, agama Islam, Hindu dan Kristen serta agama lainnya. Khususnya melalui kearifan lokal masossor manurung.

Ritual Masossor Manurung beserta pesan-pesan leluhur perlu diinfiltrasikan ke dalam bahan bacaan di sekolah utamanya untuk anak-anak usia dini. Sehingga mereka mampu sejak awal mengetahui, membaca dan melihat pesan-pesan kearifan lokal yang memuat damai di Sulawesi Barat.

\section{UCAPAN TERIMA KASIH}

Ucapan terima kasih haturkan kepada Kepala Balai Penelitian dan Pengembangan Agama Makassar yang telah menugaskan peneliti di Provinsi Sulawesi Barat tepatnya di Kabupaten Mamuju. Begitu pula Bapak DR Abd Kadir Massoweang, M.Ag. dan Prof Idham Khalid yang telah menelaah dan melakukan pembimbingan tahap demi tahapan dalam proses penyelesaian penelitian. Seluruh informan di lapangan yang tidak bisa disebut satu persatu, atas bantuannya dan partisipasinya kepada peneliti dalam pengumpulan data lapangan.

\section{DAFTAR PUSTAKA}

Ahmad, Rumadi. 2019. "Penguatan Moderasi Beragama." Kompas, 2019.

Ansaar. 2006. "Upacara Tradisional Massossor Manurung Di Kabupaten Mamuju Sulawesi Barat." Makassar.
Arifin, Samsul. 2009. Studi Agama; Perspektif Sosiologi Dan Isu-Isu Kontemporer. UMM Press.

Arifuddin. 2006. "Perkawinan Orang Mandar Persentuhan Tradisi Dan Nilai Islam Dalam Membangun Keluarga Sakinah." In Sistem Perkawinan Di Sulawesi Barat, edited by Abd Kadir Ahmad. Makassar: Indobis Publishing.

Dkk, Aholiab Watloly. 2016. Perdamaian Berbasis Adat Orang Basudara. Edited by Rosa Delima. 3rd ed. Daerah Istimewa Yogyakarta.

Dokhi, Mohammad \& Teodora Hadumaon Siagian Dkk. 2016. Analisis Kearifan Lokal Ditinjau Dari Keragaman Budaya. Jakarta: Kementerian Pendidikan dan Kebudayaan.

Geetz, $\quad$ Clifford. 2019. "(Seputariilmu.Com/2019/05/." Masyarakat-MultikuturalMenurut-Para-Ahli.Html. 2019. Idham. 2019a. Moderasi Dalam Budaya Masyarakat Islam. 1st ed. Jakarta.

Idham, Saprillah. 2011. Malaqbiq Identitas Orang Mandar. Edited by Abd Rahman Halim. 1st ed. Yogyakarta: Arti Bumi Intaran Publishing.

Imarah, Muhammad. 1999. Islam Dan Pluralitas (Perbedaan Dan Kemajemukan Dalam Bingkai Persatuan. 1st ed. Jakarta: Gema Insani.

J.Goodman, George Ritzer \& Douglas. 2007. Teori Sosiologi Modern. 6th ed. Jakarta: Prenada Media Group.

Kajian pustaka.com/2017/09/. 2017. "Pengertian-Fungsi-DimensiKearifan-Lokal.Html.No Title." Pengertian-Fungsi-DimensiKearifan-Lokal.Html. 2017.

Kampil, Abdul Rasyid. 2000. 
"Manurung Suatu Telusuran Ekpresi Balada Abad XV Masehi Di Mamuju." Mamuju.

Komariah, Djam'an Satori \& Aan. 2009. Metodologi Penelitian Kualitatif. Edited by Riduwan. 1st ed. Bandung: Alfabeta.

Maula, M Jadul. 2019. Islam Berkebudayaan Akar Kearifan Tradisi, Ketatanegaraan, Dan Kebangsaan. 1st ed. Yogyakarta: Diandra Creative.

Musahasyimmm. 2020. "Shame On You India, Sebuah Tagar Kecaman Warga Terhadap In Toleransi India." Kompasiana Beyond Blogging. 2020.

Muslim, Abu. 2019. "Iko Iko Siala Tangang (Tracing Moderatism of Religious Concept From the Oral Traditions of Bajau." In International Conference on Religion and Education. Jakarta.

Repository.usu.ac.id. 2011. "Konsep, Kerangka, Teori Dan Kajian Pustaka."

Bistream/Handle/123456789/5956 9. 2011.

Robert, Gurr Ted. 1995. "Minorities at Risk: Global View of Etnopolotical Conficcts." Wangsington.

Rudyard, Kipling. 1990. "The Ballad Of East and West" Harold Coward, Derridda End Indian Philosophy. New York: Universitity of New york.

Rumahuru, Yance Zadrak. 2012. Islam Syariah Dan Islam Adat Kinstruksi Identitas Keagamaan Dan Perubahan Sosial Di Kalangan Komunitas Muslim Hatuhaha Di Negeri Pelauw. 1st ed. Jakarta: Kementerian Agama RI.
Ruslan, Idrus. 2018. "Dimensi Kearifan Lokal Masyarakat Lampung Sebagai Media Resolusi Konflik." Kalam 12 (1 Juni).

Shihab, M. Quraish. 2019. Wasathiyyah (Wawasan Islam Tentang Moderasi Beragama. Tangerang: Lentera Hati.

Student, Indonesia. n.d. "(Pengertianmenurutparaahli.Net/ Pengertian-Kearifan-LokalSecara-Umum/Perdamaian."

Thahir, Ince Abd Rahman. 2006. Selayang Pandang Sejarah Adat, Kabupaten. Mamuju.

Tim, Kementerian Agama. 2019. Moderasi Beragama. 1st ed. Jakarta Pusat: Badan Litbang dan Diklat Kementerian Agama RI.

Tim, Kementerian Agama, and Penyusun Tafsir Tematik Kementerian RI. 2012. Moderasi Islam (Tafsir Al-Qur'an Tematik). Edited by Muchlis M. Hanafi. 1st ed. Jakarta Timur: Lajnah Pentashihan Mushaf Al-Qur'an.

Turner, Bryan s. 2012. Teori Sosial (Dari Klasik Sampai Postmodern). Yogyakarta: Pustaka Pelajar. Wahyudianto. 2011. "Teori Kebijakan." Eko. Blogspot.Com. 2011.

Walzer, Michael. 1997. On Toleration,. London: New Haven and London: Yale University Press.

Yin, Robert K. 1996. Studi Kasus Desain \& Metode. 1st ed. Jakarta: PT Raja Grafindo Persada. 